\title{
PENDEKATAN INDUKTIF UNTUK MENINGKATKAN KEMAMPUAN GURU DALAM PEMBELAJARAN MATEMATIKA SEKOLAH DASAR
}

\author{
Sandra Bayu Kurniawan, Sularmi, Anesa Surya, Siti Istiyati dan Hadiyah \\ Universitas Sebelas Maret (UNS), Indonesia \\ Email: sandrabayukurniawan@gmail.com, anesasurya@staff.uns.ac.id, \\ siti_ipgsd@yahoo.co.id, sularmi@staff.uns.qac.id dan hadiyah@staff.uns.ac.id
}

\section{Abstract}

The purpose of this study was to describe the design formulation of an inductive approach to mathematics learning for elementary school teachers with nonmathematics backgrounds. This type of research is a mixed qualitative and quantitative research and development approach. Data collection techniques using: questionnaires, interviews, and documentation. The development model used is the analyze, design, develop, implement, and evaluation (ADDIE).The results of the research, namely: (1) maximizing understanding of mathematics needs to pay attention to learning theory, (2) the mistakes made by the teacher are how to make a relationship between symbols and procedures and the availability of appropriate references, connecting symbolic procedures with informal problem solving, and connecting between symbol systems. , (3) inductive message processing, namely: starting from a special fact or event which is then linked to the previous material (prerequisite material), drafting concepts based on facts that are appropriate to the reasoning and the results of developing empirical cases, and compiling generalizations based on concepts. The conclusion of the study is the compilation of a rough model of learning mathematics with an inductive approach, with the stages: analyzing the problem; determination of the prerequisite material; determination of the facts of the problem; activities of integrating motor, affective, and cognitive domains; reasoning process; evaluation of the reasoning process; empirical case development; concept formulation; and learning evaluation.

Keywords: inductive approach; teacher's ability; mathematics learning

\begin{abstract}
Abstrak
Tujuan penelitian ini adalah mendeskripsikan rumusan desain model pendekatan induktif pembelajaran matematika untuk guru sekolah dasar (SD) yang berlatar bukan dari matematika. Jenis penelitian adalah mixed kualitatif dan kuantitatif dengan pendekatan research and development. Teknik pengumpulan data dengan menggunakan: angket, wawancara, dan dokumentasi. Model pengembangan yang digunakan adalah model analyze, design, develop, implement, dan evaluation (ADDIE). Hasil penelitian, yaitu: (1) memaksimalkan pemahaman matematika perlu memperhatikan teori belajar, (2) kesalahan yang dilakukan guru adalah bagaimana membuat hubungan antara simbol dan prosedur serta ketersedian referensi yang sesuai, menghubungkan prosedur simbolik dengan penyelesaian masalah informal, serta menghubungkan antar sistem simbol, (3) pengolahan pesan secara induktif,
\end{abstract}


yaitu: diawali dari fakta atau peristiwa khusus yang selanjutnya dihubungakan dengan materi sebelumnya (materi prasyarat), penyusunan konsep berdasarkan faktafakta yang sesuai penalaran dan hasil pengembangan kasus empiris, dan penyusunan generalisasi berdasarkan konsep-konsep. Kesimpulan penelitian adalah tersusunnya model kasar pembelajaran matematika dengan pendekatan induktif, dengan tahapan: menganalisis permasalahan; penetapan materi prasyarat; penetapan fakta masalah; kegiatan integrasi ranah motorik, afektif, dan kognitif; proses penalaran; evaluasi proses penalaran; pengembangan kasus empiris; perumusan konsep; dan evaluasi pembelajaran.

Kata kunci: pendekatan induktif; kemampuan guru; pembelajaran matematika

\section{Coresponden Author}

Email: sandrabayukurniawan@gmail.com Artikel dengan akses terbuka dibawah lisensi

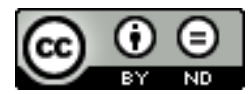

\section{Pendahuluan}

Pengertian matematika sebagai bahasa simbol (bersifat abstrak) masih bertahan pada mindset guru sekolah dasar (SD), terutama guru yang berlatar belakang pendidikan bukan dari matematika. Hal ini berpengaruh pada pembelajarannya, dimana metode yang dipergunakan adalah transfer konten matematika kepada peserta didik dan bersifat mekanik. Kondisi ini nampak dari sarana buku ajarnya. Untuk bisa memahami simbol matematika tersebut, guru cenderung memanfaatkan buku teks yang ada di sekolah dan lembar kerja peserta didik dalam kegiatan pengajaran sehari-hari.

Memperhatikan tahapan teori belajar dari Bruner, kegiatan teaching yang dilakukan guru pada saat ini, diduga telah menghilangkan tahapan konkrit dan semi konkrit. Hal ini dapat diduga, guru belum menguasai aplikasi atau implikasi tahapan pembelajaran dari teori belajar Bruner dan belum memahami hubungan pola-pola dalam matematika sekolah. Joice (Usman, 2017) menyatakan: tahapan belajar menurut teori belajar Bruner adalah enactif, ikonic, dan symbolic. Tahapan pembelajaran yang dihilangkan adalah pada tahapan enactif. Pengertian tahapan ini, dipahami sebagai tahapan untuk membangun pengetahuan berdasarkan potensi yang dimiliki peserta didik sesuai dengan perkembangannya. Pada tahapan enactif, konsep matematika dibangun berdasarkan kegiatan pengamatan secara terperinci yang bertujuan untuk membangun pengertian (mengeneralisasikan) atau definisi non-formal menurut logika peserta didik, dan akhirnya membangun teori atau konsep. Tahapan tersebut sering disebut dengan membangun pengetahuan matematika berdasarkan pengalaman empiris peserta didik.

Pembelajaran dengan pendekatan induktif sejalan dengan amanah kurikulum 2013, dimana pembelajaran yang dilaksanakan merujuk pada pendekatan saintifik. Mengeksplrorasi fakta-fakta konkrit, mensintesakan beberapa konsep atau teori secara empiris, dan membangun teori atau konsep matematika, merupakan alur pendekatan saintifik yang bersifat induktif. Pendekatan saintifik tersebut cenderung memberikan 
waktu kepada guru untuk melakukan pengamatan secara terperinci, sehingga dapat mengembangkan secara seimbang ranah motorik, afektif, dan kognitif. Konsep pembelajaran dengan pendekatan induktif inilah yang diduga tidak dipahami dan dimengerti oleh guru yang memiliki latar belakang pendidikan sarjana bukan dari matematika. Hasil observasi pra-penelitian menyebutkan bahwa indikator belum dipahami dan dimengerti. Pembelajaran dengan pendekatan induktif adalah: 1) tiap-tiap kompetensi matematika dipandang sebagai bentuk kompetensi yang bersifat parsial, tidak ada hubungan tiap-tiap kompetensi (pola-pola matematika), 2) mengidentitaskan tiap obyek dengan penyebutan yang sama, dan 3) sistematika dari struktur matematika sering kali tumpang tindih.

Kegiatan pembelajaran matematika dengan pendekatan induktif dalam penelitian ini perlu dirumuskan dalam bentuk desain model pembelajarannya. Model tersebut selain bersifat pembelajaran yang mengimbangkan perkembangan ranah motorik, afektif, dan kognitif, juga efektif dalam peningkatan kompetensi guru SD dalam penguasaan konten matematika. Model pembelajaran dengan pendekatan induktif, kegiatan-kegiatannya dalam membangun konsep matematika, sejalan dengan teori belajar Piaget. Adapun ciri peserta didik di sekolah dasar, yakni: cara berpikir operasionalnya pada tahap konkret dan pada ranah sosialnya, peserta didik suka berkelompok dan bermain. Kondisi inilah yang mendorong pentingnya penelitian untuk membangun model pembelajaran matematika dengan pendekatan induktif.

Berpikir induktif dalam prosesnya berlangsung dari khusus ke yang umum. Tokoh pendekatan induktif adalah filosof Prancis Bacon dari Inggris. (Evans, 2014) yang menyatakan bahwa: "inductive approach, also known in inductive reasoning, starts with the observations and theories are proposed towards the end of the research process as a result of observations". Pernyataan tersebut memberi pemahaman bahwa pendekatan induktif sama halnya dengan penalaran induktif, sehingga pada tahapan awal dimulai dengan pengamatan dan teori atau konsep mata pelajaran diberikan pada akhir. Sistematika ini mengisyaratkan bahwa untuk membangun pengetahuan yang bersifat umum, tahapan membangun pengetahuan didasarkan oleh pengamatan serta pencermatan fakta-fakta konkrit yang banyak diperoleh oleh responden, sebagai dasar pembentukan pengetahuan dan bersifat empiris. Menurut (Saunders, Lewis, \& Thornhill, 2012) menyatakan bahwa: "inductive reasoning is based on learning from experience. Patterns, resemblances and regularities in experience (premises) are observed in order to reach conclusions (or to generate theory)". Pernyataan tersebut memberi masukan bahwa penalaran induktif itu belajar dari pengalaman (premis). Memahami pola-pola, kemiripan, dan keteraturan dalam pengalaman yang pada akhirnya membangun kesimpulan atau menghasilkan teori. Hal ini sejalan dengan pendapat (Trinato, 2018) yang menyatakan bahwa: "berpikir Induktif merupakan cara berpikir yang digunakan apabila seseorang membuat kesimpulan berdasarkan informasi atau fakta yang dimiliki dan berdasarkan prinsip-prinsip penemuan, serta dibuat dari yang spesifik ke yang umum". 
Pembelajaran dengan pendekatan induktif memiliki tahapan yang sama dengan penelitian induktif, yakni bersifat sistematik dan menyesuaikan dengan tahapan teori belajar. (Evans, 2014) menyatakan bahwa: "inductive research "involves the search for pattern from observation and the development of explanations - theories - for those patterns through series of hypotheses". Pernyataan tersebut memberikan pemahaman bahwa penelitian induktif dalam pengamatan berusaha untuk mencari pola-pola yang kemudian memberikan penjelasan hubungan antar pola melalui teori berdasarkan hipotesis. Hal ini dipertegas oleh (Wena, 2017) yang menyatakan bahwa: "pengolahan pesan secara induktif bermula dari (i) fakta atau peristiwa khusus, (ii) penyusunan konsep berdasarkan fakta-fakta, (iii) penyusunan generalisasi berdasarkan konsepkonsep". Berdasarkan pengertian di atas, dapat didefinisikan bahwa pendekatan induktif adalah proses membangun pengetahuan yang diawali dengan pemilihan konsep atau prinsip yang disajikan dalam bentuk khusus dan secara sistematika dibimbing membangun konsep atau prinsip yang bersifat umum.

Kemampuan dalam bahasa Inggris menjadi competence. Dalam penelitian ini, kata kompetensi dihubungkan dengan kompetensi guru. (Weinstein, 2015) menyatakan bahwa: "competency is underlying characteristic of an individual that is causally related to criterion-referenced effective and/or superior performance in a job or situation". Pernyataan tersebut memberikan pemahaman bahwa kompetensi adalah karakteristik dasar yang dimiliki seseorang dan berkaitan dengan kinerja berkriteria efektif serta unggul dalam suatu pekerjaan atau situasi tertentu. Dari pernyataan tersebut, bagian yang menjadi fokus kompetensi adalah pada kata underlying characteristic. Hal ini dikarenakan, karakteristik itu merupakan bagian yang terpenting dan melekat pada kepribadian seseorang dan dapat memprediksi berbagai situasi dan jenis pekerjaan. Fokus yang kedua adalah causally related. Hal tersebut dikarenakan kompetensi dapat menyebabkan atau memprediksi perilaku dan kinerja. Selanjutnya, fokus yang ketiga adalah criterion-referenced. Hal ini dikarenakan melalui kompetensi dapat diprediksi siapa-siapa saja yang kinerjanya baik atau buruk, berdasarkan kriteria atau standar tertentu.

(Weinstein, 2015) menyatakan bahwa: "a competency is composed of skill, knowledge, and attitude, but in particular the consistent applications of those skill, knowledge, and attitude to the standard of performance required in employment". Pernyataan tersebut memberi masukan bahwa pada dasarnya kompetensi tidak hanya mengandung pengetahuan, keterampilan dan sikap, namun yang lebih urgen adalah bagaimana menerapkan pengetahuan, keterampilan, dan sikap dalam pekerjaan (menjadi guru). Hal ini juga diperkuat oleh (Usman, 2017) yang menyatakan bahwa: "kompetensi merupakan kemampuan dan kewenangan guru dalam melaksanakan profesi keguruannya guru". Selanjutnya, (Muhaimin, 2004) menyatakan bahwa: "kompetensi adalah seperangkat tindakan intelegen penuh tanggung jawab yang harus dimiliki seseorang sebagai isyarat untuk dianggap mampu melaksanakan tugas-tugas dalam bidang tertentu. Sifat intelegensi harus ditunjukkan sebagai kemahiran ketetapan, dan keberhasilan bertindak". Berdasarkan pengertian di atas, dapat ditarik pemahaman 
bahwa kompetensi guru adalah kecakapan guru dalam melaksanakan kegiatan yang didasari oleh intelegensinya untuk menata dan menyampaikan pesan materi pelajaran dengan tepat, efektif, dan berhasil.

Kata pembelajaran berasal dari kata belajar, sehingga perlu adanya pengertian tentang apa itu belajar. (Chueachot, 2013) menyatakan bahwa: "learning is the process by witch an activity orginates or is changed through training prosedure (wheter in the laboratory or in natural environment) as distringuished from changes by factor not atributtable to training". Pernyataan tersebut memberi pemahanan bahwa belajar adalah suatu proses yang sebelum dan sesudah melakukan aktivitas akan dapat diperhatikan perubahannya yang disebabkan bukan aktivitas tersebut. (Johnson, 2012) menyatakan bahwa: "learning is shown by change in behavior as a result of experince". Pernyataan tersebut memberi pemahaman bahwa belajar memberikan perubahan tingkah laku dari hasil pengalaman. Berdasarkan pengertian tersebut, dapat dimengerti bahwa melalui belajar akan mengembangkan perubahan tingkah laku karena adanya penguasaan ilmu pengetahuan dan sikap sebagai pembentukan pengalaman yang secara sengaja.

Memperhatikan pengertian belajar, perlu adanya penegasan tentang pengertian pembelajaran. Dalam kegiatan penelitian mandiri aktif pengertian pembelajaran merujuk dari (Johnson, 2012) yang menyatakan bahwa: "ä relatively permanent change in response potentiality which occurs as a result of reinforced practice" dan " $a$ change in human disposition or capability. Which can be retained, and which is not simply ascrible to the process of growth". Pernyataan tersebut memberikan tiga prinsip, yaitu belajar menghasilkan perubahan tingkah laku yang bersifat permanen, peserta didik memiliki potensi yang merupakan benih kodrati yang harus ditumbuh kembangkan, dan pencapaian kualitas ideal tidak tumbuh alami linear sejalan dengan kehidupan.

Teori belajar yang menjadi rujukan untuk diperhatikan adalah perkembangan intelektual peserta didik dari Piaget. (Wena, 2017) menyatakan bahwa: "tahapan perkembangan intelektual anak berusia 7 sampai 12 tahun adalah pada tahapan praoperasional konkrit, yang dicirikan: perkembangan pemikiran yang dijalankan secara terbalik, operasi-operasi logis, konservasi, mampu memecahkan masalah konkrit, dan pemikirannya berbasis pengalaman". Selanjutnya, untuk memperkuat pelaksanaan penelitian mandiri juga dirujuk teori belajar Bruner. Teori ini dideskripsikan oleh (Chueachot, 2013) yang menyatakan bahwa: "perkembangan pemikiran siswa melalui konsep mode representasi (modes of representation) yang urutannya sudah tetap, yaitu: enactive mode of representation, iconic mode of representation, and symbolic mode of representation”. Aplikasi dari teori belajar Bruner dalam teori pembelajaran adalah pembelajaran yang dilaksanakan guru agar peserta didik mau untuk belajar, perlu ada tahapan-tahapannya, yaitu: tahapan konkrit, semi konkrit dan semi abstrak, serta abstrak.

Tahapan untuk melihat tingkat pemahaman mempelajari matematika dikemukakan oleh In (Siregar, 2018) yang menyatakan bahwa: "the mathematics is understood if its mental representation is part of a network of representations. The degree of 
understanding is determined by the number and strength of its connections. A mathematical idea, procedure, or fact is understood thoroughly if it is linked to existing networks with stronger or more numerous connections". Pernyataan tersebut memberikan masukan bahwa matematika dapat dipahami apabila representasi mentalnya adalah bagian dari jaringan representasi. Tingkat pemahaman ditentukan oleh banyak dan kekuatan koneksinya. Gagasan, prosedur, atau fakta matematika dipahami secara menyeluruh jika benar terhubung ke jaringan yang ada koneksinya.

In (Siregar, 2018) menyatakan bahwa: In light of these points, we can consider different ways in which we can assess this understanding. Possible methods suggested by (Hiebert \& Carpenter, 1992) were to analyse:

1. Students' errors.

2. Connections made between symbols and symbolic procedures and corresponding referents.

3. Connections between symbolic procedures and informal problem solving situations.

4. Connections made between different symbol systems.

Pernyataan tersebut menandaskan bahwa metode untuk dapat meningkatkan pemahaman matematika, hal-hal yang perlu dianalisa adalah: tingkat kesalahan siswa (dalam hal ini guru) bagaimana membuat hubungan antara simbol dan prosedur serta ketersedian referensi yang sesuai, menghubungkan prosedur simbolik dengan penyelesaian masalah informal, serta menghubungkan antara antar sistem simbol. Prosedur di atas telah banyak diteliti dengan berfokus pada cara menganalisis materi pelajaran. Salah satu peneliti, Winahyu Arif yang berfokus pada menganalisis konten mata pelajaran ilmu pengetahuan sosial (IPS) SD, dengan judul penerapan model berpikir induktif untuk meningkatkan hasil belajar IPS. Perbedaan dengan penelitian ini adalah bukan hanya menganalisis materi pembelajaran matematika saja tetapi bagaimana membangun model pembelajaran.

\section{Metode Penelitian}

Pendekatan penelitian adalah mixed kualitatif dan kuantitatif dengan jenis research and development. Teknik pengumpulan data untuk penelitian tahun pertama adalah dengan menggunakan: angket, wawancara, dan dokumentasi. Sedangkan, hasil penelitian ini adalah model pengembangan pembelajaran matematika dengan pendekatan induktif untuk guru SD yang berlatar belakang bukan dari matematika atau pendidikan matematika. Selanjutnya, hasil penelitian akan diwujudkan dalam bentuk buku suplemen dengan pendekatan induktif matematik. Model pengembangan yang digunakan dalam penelitian ini, melalui tahapan pengembangan: analyze, design, develop, implement, dan evaluation (ADDIE). Pelaksanaan kegiatan penelitian tahun pertama pada bulan Maret sampai Oktober 2019 di kecamatan Piyungan dan Imogiri kabupaten Bantul. Sampel penelitian adalah guru sebanyak 37 (tiga puluh tujuh) orang yang memiliki latar belakang bukan dari matematika atau pendidikan matematika. 
Prosedur pengembangan model pembelajaran dengan pendekatan induktif mengaplikasikan tahapan model pengembangan ADDIE yang dapat dilihat pada Gambar 1.

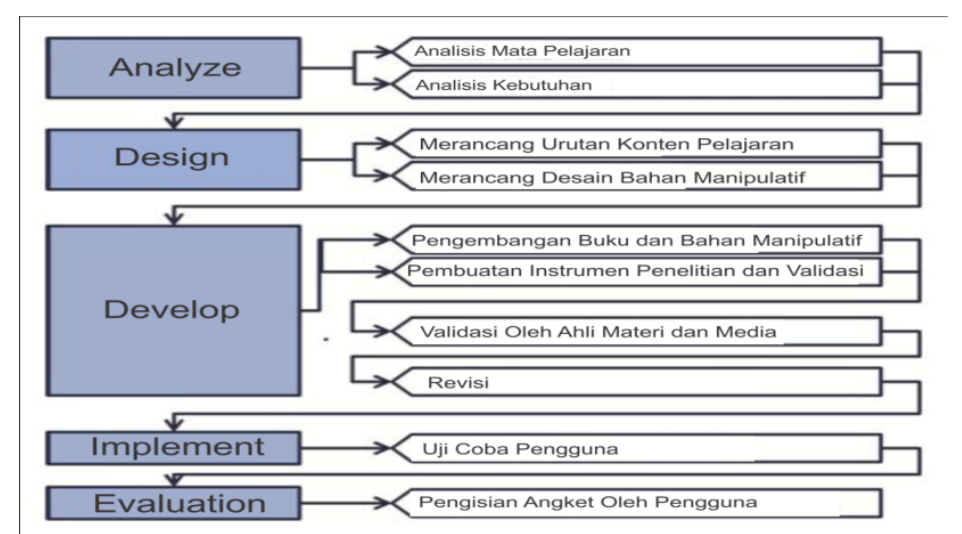

Gambar 1

Prosedur Pengembangan - (Trinato, 2018)

\section{Analyze (Analisis)}

Pada tahapan awal, peneliti melakukan kegiatan diskusi dengan Dr. Maria Dominika Niron, M.Pd., selaku dosen Ilmu Pendidikan di Universitas Negri Yogyakarta. Diskusi ini untuk mendapatkan informasi, diskusi, serta mengalisis cara memperoleh dan mengolah data yang dibutuhkan dalam kegiatan penelitian, yang meliputi:

a. Analisis Mata Pelajaran

Analisis mata pelajaran dilakukan dengan tujuan untuk mengetahui domain matematika di SD, mengetahui kesalahan konsep dan merumuskan serta menyusun hubungan persyaratan tiap-tiap tahapan pembelajaran matematika SD.

b. Analisis Kebutuhan

Analisis kebutuhan pada penelitian ini difokuskan pada pemilihan bahan manipulatif dan sintaks penggunaannya, serta pendeskripsiaan membangun konsep matematika. Pemilihan media ini untuk memperhatikan kontribusi media dalam membangun kesesuaian antara logika guru dalam memahami proses membangun dan meningkatkan pemahaman konsep matematika.

\section{Design (Desain)}

Tahapan mendesaian dilakukan untuk menyusun urutan materi matematika SD, materi prasyarat pembelajaran tiap tahapan dari teori bilangan, mendesain pemanfaatan bahan manipulatif serta media pembelajaran, dan bentuk evaluasi. Penyusunan ini untuk memperhatikan struktur pembelajaran matematika agar sesuai dengan logika guru dan pembelajaran yang diperkirakan akan efektif dan efisien. Hasil penyusunan pendesaianan adalah model pembelajaran masih dalam bentuk kasar tetapi telah disesuaikan dengan hasil tahapan analisis. 


\section{Development (Pengembangan)}

Pada tahapan pengembangan dilakukan proses pengembangan urutan konten buku, pemilihan bahan manipulatif, sintaks pemanfaatan media tersebut dalam proses membangun konsep matematika, dan bentuk evaluasi, sehingga diharapkan dapat terbentuk model pembelajaran dengan pendekatan induktif yang siap di ujicobakan. Pada tahap ini peneliti melakukan kegiatan sebagai berikut:

a. Pengembangan urutan konten teori bilangan.

b. Pengembangan pemilihan bahan manipulatif serta sintaks pemakaiannya.

c. Pengembangan bentuk evaluasi pembelajaran

d. Pembuatan instrument penelitian dan validasi yang meliputi: pembuatan instrumen penelitian untuk ahli materi, ahli media dan pengguna (guru), serta memvalidasi intrumen kepada ahli instrumen (expert judgement) sehingga layak digunakan. Untuk tahun pertama, target penelitian adalah terbentuknya model pembelajaran matematika dengan pendekatan induktif. Sehingga, instrument validasi akan dirumuskan pada tahan tahun ke dua penelitian.

e. Uji validasi ahli materi dan media yang meliputi: pengujian produk dari segi materi oleh ahli materi, dan pengujian produk dari segi media oleh ahli media sehingga layak untuk dilakukan uji coba kepada siswa SD. (Dilaksanakan pada tahun ke dua penelitian).

f. Revisi produk berdasarkan saran dari ahli media dan materi. (Dilaksanakan pada tahun ke dua penelitian).

\section{Implementation (Penerapan)}

Hasil desain model pembelajaran dengan pendekatan induktif pada tahun pertama penelitian, akan diujicobakan pada tahun ke dua penelitian. Sebelum diujicobakan ke sekolah yang lain, model akan divalidasi oleh ahli materi dan ahli media untuk mengetahui kelayakannya. Hasil validasi apabila dinyatakan layak untuk digunakan, maka dapat diujicobakan atau diterapkan kepada guru dan sekolah lain. Uji coba dilakukan agar guru dapat memberikan penilaian dan saran tentang model pembelajaran dengan pendekatan induktif.

\section{Evaluation (Evaluasi)}

Tahapan evaluasi dilaksanakan pada tahun ke dua penelitian. Adapun kegiatan pada tahapan ini, model pembelajaran dengan pendekatan induktif matematika SD dievaluasi dengan penyebaran angket kepada guru untuk dinilai, yang selanjutnya dianalisis untuk mengetahui tingkat kelayakannya dipergunakan secara umum.

\section{Hasil dan Pembahasan}

\section{A. Hasil Penelitian}

Kegiatan penelitian tahun pertama pada tahapan analisis mata pelajaran, peneliti mengajukan pertanyaan "sebutkan domain matematika SD". Sasaran dari pertanyaan ini adalah guru memahami domain yang akan diajarkan sehingga mampu membuat tahapan-tahapan pembelajaran dan mampu menghubungkan antara materi prasyarat dengan materi yang akan diajarkan. Jawaban dari 
pertanyaan tersebut didapatkan data bahwa pemahaman semua guru terhadap pengetahuan domain matematika SD adalah belum dipahami secara utuh. Apa yang disebutkan dalam pertanyaan domain matematika SD adalah sub atau subsub kompetensi matematika SD. Materi yang disebutkan guru-guru dari pertanyaan domain matematika SD adalah materi ajar yang saat menjadi materi pembelajaran guru-guru tersebut. Materi-materi yang diajarkan guru belum memahami masuk dalam pengelompokan domain matematika SD yang mana. Kondisi ini memberikan masukan bahwa tekstualisasi menjadi kekuatan utama dalam pembelajaran guru-guru yang bukan dari matematika atau pendidikan matematika.

Tahapan pertanyaan selanjutnya adalah pengertian angka, bilangan, dan nomor. Pertanyaan ini perlu diberikan guna mengurangi kesalahan penyebutan saat proses pembelajaran dan menggiring pada materi prasyarat sebelum materi inti tersebut diberikan. Dari data jawaban pertanyaan diperoleh masukan bahwa semua guru menyatakan bahwa angka, bilangan, dan nomor adalah sama. Kondisi ini memberikan masukan bahwa guru belum memahami dengan baik, tentang: materi matematika tidak nampak sebagai pengetahuan tentang struktur logis yang terorganisir dan pengetahuan matematika dipahami sebagai pengetahuan tentang aturan-aturan yang tidak ketat.

Pembelajaran mengenalkan angka belum didasari konsep yang benar. Hal ini nampak dari membedakan pemilihan dan penyebutan kata "jumlah" dan "banyak" pada saat pembelajaran mengenal angka. Proses mengenal angka adalah proses kegiatan menyimbolkan dari banyaknya benda konkret atau semi. Hasil pengumpulan data, diperoleh masukan bahwa materi prasyarat mengenalkan angka belum dipahami dengan baik. Aktivitas pembelajaran yang dilakukan guru adalah memperhatikan isi buku yang dijadikan pegangan pembelajaran. Kondisi tersebut menjadi salah satu sumber kurangnya guru berkreasi untuk mengaplikasikan teori belajar tentang tahapan konkret, semi, dan abstrak.

Pertanyaan seputar bilangan bulat bertujuan untuk mengungkap kesiapan pembelajaran guru dalam menjelaskan operasi matematika yang memiliki dua obyek yang berlawanan dan satu bilangan netral. berdasarkan data yang diperoleh dapat dideskripsikan sebagai berikut: (1) Semua guru memahami anggota bilangan bulat, yaitu: ..., $-3,-2,-1,0,1,2,3, \ldots$, sehingga setiap pembelajaran guru bersifat sebagai informan yakni memberitahukan siapa saja anggota bilangan bulat. (2) Guru tidak menekankan bahwa bilangan bulat terdiri dari dua kelompok bilangan yang saling berlawanan dan satu bilangan netral yakni 0 (nol). Kondisi ini menyebabkan: a. cara membacanya sering kali dianggap tidak konsisten, misalkan pada soal operasional $4--3=\cdots$, terdapat 21 guru cara membacanya "empat dikurangi negatif tiga", dan 16 guru cara membacanya "empat min min tiga". b. 25 guru menganalogikan simbol operasional negatif dengan konteks hutang. Kondisi ini pada saat bilangan yang dioperasionalkan 
sejenis tidak mengalami hambatan untuk penalarannya, tetapi saat $4--3=\cdots$ guru mengalami kesulitan untuk menjelaskan. c. Untuk mengatasi hal ini, guru mengatasi pemahaman yang simpang siur, guru mengambil langkah kebijakan dengan membuat ringkasan atau tabel yang dapat disimpulkan dengan deskripsi: bila ada dua tanda yang sama berdampingan maka dapat diubah menjadi simbol operasional + dan bila ada dua tanda yang berbeda berdampingan maka dapat diubah menjadi simbol - . Kondisi telah mengkaburkan peranan bilangan 0 (nol), penjelasannya telah melompat ke operasional perkalian yang seharusnya belum dilalui, dan guru belum memahami simbol operasional dan simbol daerah atau kelompok bilangan. (3) Operasional perkalian dan pembagian antara dua kelompok bilangan dalam pembelajaran lebih didominasi penjelasannya pada operasional perkalian. Baik dari sisi waktu pertemuan maupun contoh soal. Keadaan ini, dari hasil perolehan data, dapat dideskripsikan bahwa guru mengalami kusulitan cara menjelaskan yang sesuai dengan logika, yakni misalkan pada antara $\frac{-8}{2}$ dengan $\frac{8}{-2}$. Kondisi ini, guru mengambil langkah kebijakan dengan membuat ringkasan, yaitu: bila tandanya berbeda maka dapat diubah menjadi - dan bila tandanya sama maka dapat diganti +. Kondisi ini telah mengkaburkan tahapan pembelajaran yang mengembangkan penalaran siswa walaupun hasil perolehan operasionalnya benar.

\section{B. Pembahasan}

Memaksimalkan pemahaman matematika perlu memperhatikan teori belajar Piaget. Proses asimilasi maupun akomodasi adalah menuntun untuk penyusunan materi prasyarat konten matematika yang akan diajarkan. Teori Piaget jadi dasar pembahasan dikarenakan guru-guru bukan matematika atau bukan dari pendidikan matematika, pada dasarnya telah memiliki beberapa konsep tentang matematika. Konsep tersebut bisa dari pengalaman sewaktu belajar di bangku sekolah maupun saat mempelajari buku pelajaran yang digunakan untuk mengajar.

Kesalahan yang sering dilakukan adalah bagaimana membuat hubungan antara simbol dan prosedur serta ketersedian referensi yang sesuai, menghubungkan prosedur simbolik dengan penyelesaian masalah informal, serta menghubungkan antara simbol matematik dengan penginterprestasiannya. Kesalahan-kesalahan ini perlu dianalisis yang selanjutnya dikurangi secara bertahap dan sistematis melalui penetapan tahapan demi tahapan sesuai model pembelajaran induktif. Tahapan enactif diwujudkan dengan benda nyata, tahapan iconic diwujudkan dengan model atau gambar visual, sedangkan tahapan symbolic diwujudkan dalam bentuk deskripsi. Model pendekatan induktif tersebut diharapkan mampu untuk memahami bahwa matematika adalah cabang ilmu pengetahuan eksak dan terorganisir secara sistematik, pengetahuan tentang bilangan dan kalkulasi, pengetahuan tentang penalaran logis dan berhubungan dengan bilangan, pengetahuan tentang struktur-struktur logis yang terorganisasikan, dan pengetahuan tentang aturan-aturan yang ketat. 
Perlunya pendekatan induktif ini dalam pembelajaran matematika untuk guru bukan dari matematika atau pendidikan matematika, dikarenakan kemampuan guru tersebut dalam mengembangkan penalaran dilandasi adanya pengalaman matematika yang dimiliki sewaktu belajar di sekolah atau saat mempelajari buku pegangan. Konsep pendekatan induktif yang sama dengan penalaran induktif, pembelajarannya pada tahapan awal dimulai dengan pengamatan untuk membangun pengalaman empiris atau dari pengalaman sebelumnya dan selanjutnya teori atau konsep mata pelajaran matematika diberikan pada akhir pembelajaran. Hal ini sesuai dengan pernyataan (Trinato, Trinata, 2018) tentang pengolahan pesan secara induktif, yaitu: diawali dari fakta atau peristiwa khusus yang selanjutnya dihubungakan dengan materi sebelumnya (materi prasyarat) melalui asimilasi atau akomodasi; penyusunan konsep berdasarkan fakta-fakta yang sesuai penalaran dan hasil pengembangan kasus empiris dengan melibatkan kegiatan secara terintegrasi ranah motorik, afektif, dan kognitif; dan selanjutnya penyusunan generalisasi berdasarkan konsep-konsep.

Tahapan model pembelajaran matematika dengan induktif, yaitu: menganalisis permasalahan; penetapan materi prasyarat; penetapan fakta masalah; kegiatan integrasi ranah motorik, afektif, dan kognitif; proses penalaran; evaluasi proses penalaran; pengembangan kasus empiris; perumusan konsep; dan evaluasi pembelajaran; sesuai dengan teori belajar dari Bruner. Teori tersebut dimulai dari perkembangan pemikiran guru bukan matematika yang dimulai dari konsep mode representasi (modes of representation) yang urutannya, yaitu: enactive mode of representation, iconic mode of representation, and symbolic mode of representation. Pada tahapan enactive banyak berargumentasi pada tahapan yang bersifat konkret atau dapat diamati dari sekeliling guru. Hal ini sesuai dengan model pembelajaran induktif, yaitu adanya permasalahan yang dirasakan guru dan adanya materi prasyarat yang harus dimiliki dan berhubungan dengan fakta masalah yang ditetapkan. Ketiga tahapan tersebut terjadi dan dirasakan secara konkret oleh guru. Tahapan iconic dalam argumentasinya lebih berfokus pada penguraian kegiatan atau bersifat semi konkret atau semi abstrak, yakni penetapan sasaran pembelajaran. Hal ini nampak dari dilibatkannya kegiatan ranah motorik, afektif, dan kognitif sebagai sasaran untuk membantu dalam proses penalaran serta pengembangan kasus empiris. Sedangkan tahapan symbolic berfokus pada generalisasi yang bersifa abstrak. Hal ini nampak dari tahapan model pendekatan induktif yaitu perumusan konsep matematika. 


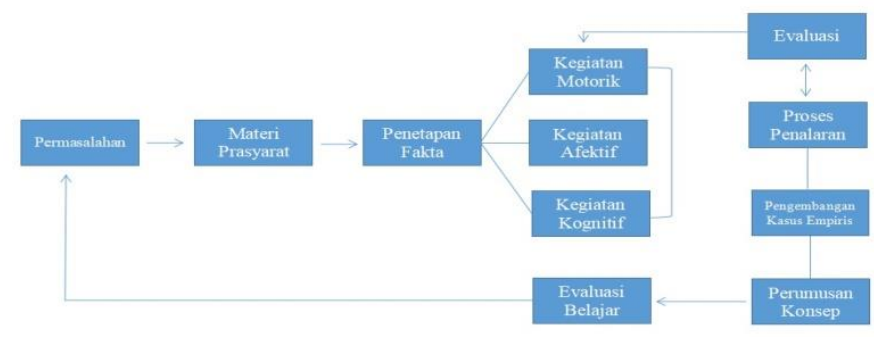

Gambar 2

Model kasar pendekatan induktif pembelajaran matematika SD

\section{Kesimpulan}

Berdasarkan uraian pada hasil kegiatan dan pembahasan di atas, dapat disimpulkan bahwa tahapan pembelajaran induktif, yaitu: memaksimalkan pemahaman teori belajar Piaget dan Bruner; memahami miskonsepsi tentang bagaimana membuat hubungan antara simbol dan prosedur serta ketersedian referensi yang sesuai, menghubungkan prosedur simbolik dengan penyelesaian masalah informal, serta menghubungkan antara simbol matematika dengan interprestasinya; memahami bahwa konsep pendekatan induktif sama dengan penalaran induktif, yang tahapan pembelajarannya meliputi pengamatan untuk membangun pengalaman empiris atau dari pengalaman sebelumnya dan selanjutnya teori atau konsep mata pelajaran matematika diberikan pada akhir pembelajaran; pengolahan pesan secara induktif, melalui tahapan: fakta atau peristiwa khusus dihubungakan dengan materi prasyarat, penyusunan konsep berdasarkan fakta-fakta yang sesuai penalaran dan hasil pengembangan kasus empiris, dan penyusunan generalisasi berdasarkan konsep-konsep. Tahapan tersebut, selanjutnya dapat disusun model kasar pembelajaran matematika dengan induktif. Tahapannya meliputi: analisis permasalahan; penetapan materi prasyarat; penetapan fakta masalah; kegiatan integrasi ranah motorik, afektif, dan kognitif; proses penalaran; evaluasi proses penalaran; pengembangan kasus empiris; perumusan konsep; dan evaluasi pembelajaran. Tahapan tersebut sesuai dengan teori belajar dari Bruner. Teori tersebut dimulai dari konsep mode representasi (modes of representation) yang urutannya, yaitu: enactive mode of representation, iconic mode of representation, and symbolic mode of representation. 


\section{BIBLIOGRAFI}

Baharudin, wahyuni (2012). Teori Belajar \& pembelajaran. Yogyakarta: Ar-Ruzz Media

Bernard, H. Russell. (2016). Sampling III: Nonprobability samples and choosing informants. Research Methods in Anthropology: Qualitative and Quantitative Approaches. 5th Ed. United Kingdom: AltaMiraPress.

Bruce Joyce, Marsha weil, dan Emily Calhoun. (2014). Models of Teaching. Pearson Education, Inc, publishing as Allyn \&Bacan, One Lake Street Upper Saddle river, USA: New Jersey.

Chueachot. S. Srisa-ard. B., \& Srihamongkol, Y. (2013). "The Development of an assesment for Leaning Model for Elementary Classroom". International Education Studies, (6(9), hlm. 119-124.

Duski Ibrahim. (2017). Filsafat Ilmu: Dari Penumpang Asing untuk Para Tamu. Palembang: Noer Fikri

Evans. S., \& Swan. M. (2014). "Developing Students' Strategies for Problem solving". Educational Designer, 77(1). hlm. 81-112

Hiebert, James, \& Carpenter, Thomas P. (1992). Learning and teaching with understanding. Handbook of Research on Mathematics Teaching and Learning: A Project of the National Council of Teachers of Mathematics, 65-97.

Johnson, Elaine B. (2012). Contextual teaching and learning: What it is and why it's here to stay. Corwin Press.

Muhaimin, Paradigma Pendidikan Islam Upaya Mengefektifkan. (2014). Pendidikan Agama Islam di Sekolah, Bandung: PT. Remaja Rosdakarya.

Reza. A. A. Wattimena. (2015). Penelitian Ilmiah dan Martabat Manusia. Jakarta: Evolitera

Reza Firmansyah. (2014). Desain Pembelajaran Kimia Bermuatan Nilai Pada SubtopikPembentukan Ikatan Ion dan Kovalen. Bandung: UPI

Saunders, Mark, Lewis, Philip, \& Thornhill, Adrian. (2012). Research methods for business students (6. utg.). Harlow: Pearson.

Siregar. S. (2018). Meningkatkan kemampuan Guru dalam menerapkan Pembelajaran Kontekstual melalui Focus Group Discussion (FGD) di SMK Negeri 1 Sirandorung Tahun pelajaran 2017/2018. NUSANTARA: Jurna Ilmu Pengetahuan Sosial, 5(1), 14-19

Trinato. (2018). Medesain Model Pembelajaran Inovatif-Progresif: Konsep, Landasan, 
Sandra Bayu Kurniawan, Sularmi, Anesa Surya, Siti Istiyati dan Hadiyah

dan Implementasinya pada KurikulumTingkat Satuan Pendidikan (KTSP). Jakarta: Kencana Prenada Media Group

Usman, Moh Uzer. (2017). Menjadi guru profesional. Bandung: PT. Remaja Rosdakarya, 154.

Weinstein, and Richard. (2015). "The Teaching of Learning Strategies". In Handbook of Research on Teaching. Edited by Merlin c. Wittrock. London: Collier Macmillan Publishers.

Wena, Made. (2017). Strategi Pembelajaran Inovatif Kontemporer: Suatu Tinjauan Konseptual Operasional. Jakarta: Bumi Aksara 